\title{
La catedral de Jaén
}

El edificio de la catedral de Jaén' se sitúa en el corazón del centro histórico de la capital de la provincia y resulta ser un paradigma arquitectónico renacentista, sintesis de la arquitectura catedralicia andaluza y la mejor reflexión y compendio de los edificios de este mismo género construidos hasta esa fecha y de los tratadistas clásicos que sirvieron de referencia para su diseño formal.

El edificio está erigido sobre un terreno de forma rectangular en el que, según las descripciones de los historiadores, se encontraba la antigua mezquita de la ciudad hispanomusulmana.

Su fachada frontal mide 75,7 metros y colinda al oeste con la plaza de Santa María que actúa como remate visual de la calle del Obispo González. Al extremo norte se encuentra la calle de las Campanas, una de las principales vías que circundan la zona; ésta conecta con las calles de la Maestra, calle de Cerón y calle Álamos, para extenderse aproximadamente 120 metros y desembocar en la plaza de San Francisco. Al este del testero de la catedral circunda la calle peatonal Valparaíso y la calle de las Almenas. Por último, en el extremo sur se encuentra la calle de la Carrera de Jesús, otra de las vías principales del centro histórico de Jaén.

Tras la experiencia de Úbeda y Baeza, Andrés de Vandelvira se encargaría de la construcción de la catedral de Jaén. Era éste un templo gótico final cuya última edificación había correspondido al obispo Suárez, pero e derrumbamiento del cimborrio en 1525 vino a señalar el irremediable final de una fábrica que, pese a las dos reforma sufridas desde que se conquistara la ciudad en el siglo XIII, seguía siendo estrecha y oscura al levantarse constreñida por el ángulo de muralla en la que

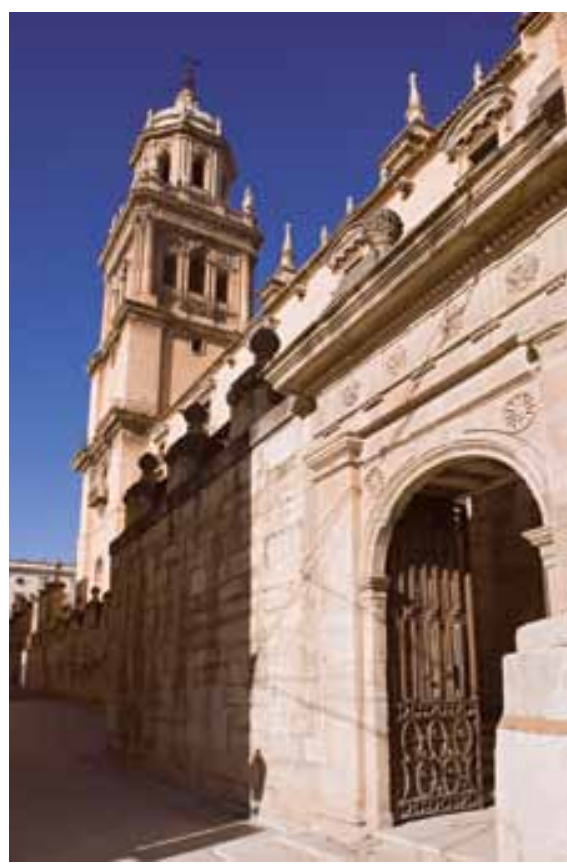

Catedral de Jaén. Fuente: Fondo Gráfico IAPH estaba prácticamente empotrada. El suceso hizo que el nuevo obispo, pensando en culminar el proyecto de sus predecesores, consiguiera de Clemente VII una bula mediante la cual se concedian indulgencias plenarias y remisión de culpas a quienes acudieran en los dias que se mostraba la reliquia del Santo Rostro y contribuyeran con su limosna a la edificación del templo.

Tras varios tanteos del Cabildo, en 1548 llama a consulta a Machuca y a Vandelvira para decidir la continuación de la obra. Sólo entonces puede decirse que se inicia el templo renacentista. Hasta 1551 no se puso la primera piedra y hasta dos años después no firma su contrato como maestro mayor de la misma Andrés de Vandelvira.

El edificio es de planta rectangular dividida en tres naves y cabecera plana, disponiéndose alrededor (excepto en el tramo de los pies) una serie de capillas hornacinas entre contrafuertes interiores. La cubierta es de bóvedas vaídas con decoración, todas ellas a la misma altura, que descansan sobre pilares cruciformes de orden corintio con doble entablamento. Una cúpula con tambor sobre pechinas y rematada con linterna sobre el crucero. Por encima de los arcos de las capillas, todo el recinto está recorrido por balcones.

La nave central está ocupada desde el crucero hasta los pies por un coro, al interior con sillerias de madera $y$ al exterior de muro de piedra dividido en dos cuerpos y rematado por una balaustrada.

Al exterior presenta dos portadas, una en cada lado del crucero, y la fachada principal a los pies:

- La portada este, obra de Vandelvira en 1560, presenta una decoración más sobria.

- La portada oeste, de Juan de Aranda, fechada en 1642, está profusamente decorada.

- La fachada principal, diseñada por López de Rojas y terminada en 1688, se enmarca entre dos torres, se estructura por medio de un orden corintio gigante de columnas pareadas que ordenan calles, a manera de retablo, ocupadas por esculturas exentas y relieves; toda ella se remata con una balaustrada sobre la que se colocan esculturas de gran tamaño; el último cuerpo de la fachada está retranqueado a la altura de la balaustrada.

Cada elemento arquitectónico y constructivo de la catedral de Jaén se encuentra tal y como fue concebido desde su traza por Andrés de Vandelvira, conservando todo un repertorio de elementos que dan clara muestra del ejemplo mejor conservado y más representativo del Renacimiento español que posteriormente fue transmitido, con la misma sinergia de conquista, hacia los territorios ocupados por los españoles en América. Su originalidad artistica influirá notablemente en numerosas construcciones militares o religiosas como las catedrales de México, Puebla, Mérida, Guadalajara, Oxaca, Lima o Cuzco, algunas también declaradas Patrimonio Mundial.

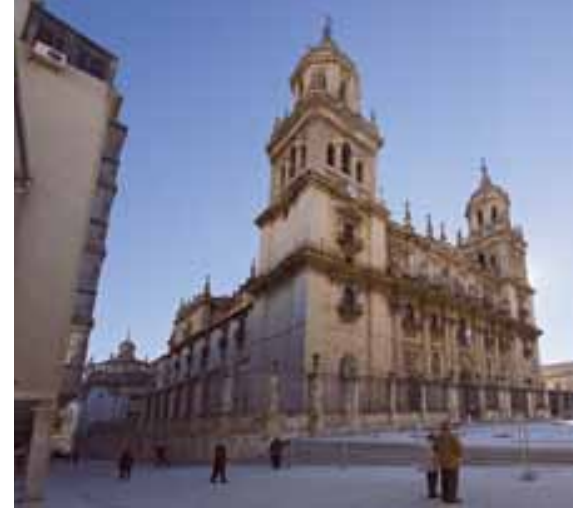

Catedral de Jaén. Fuente: Fondo Gráfico IAPH

Los elementos característicos de la catedral de Jaén constituyen un repertorio que respeta cabalmente la traza vandelviriana. Desde la planta arquitectónica -conformada por tres naves y dos alas laterales de capillas-, la forma de cruz latina cubierta por una cúpula central o el coro en la nave central, los proporcionados pilares, los amplios arcos de medio punto, las dos capillas hornacinas por tramo coronadas por balcones, las bóvedas vaídas, el alzado tipo salón que le permite una gran luminosidad del espacio, la sacristía, la sala capitular o la cripta. Todo un compendio de elementos característicos de la arquitectura de Vandelvira.

Desde el punto de vista paisajístico, la catedral de Jaén ejerce un notable protagonismo visual en la silueta urbana de la ciudad. El monumento destaca sobre la ladera del tejido histórico que configura las cotas más altas del casco antiguo, a los pies del castillo y cerro de Santa Catalina.

La catedral presenta un buen estado de conservación, con problemáticas localizadas puntualmente en las cubiertas, en las cuales se ha previsto intervenir durante los años 2010 a 2012; y en las fachadas, cuya limpieza y consolidación general se prevé en 2012.

Las autoridades eclesiásticas y los tres niveles de gobierno estatal, autonómico y municipal han contribuido a la conservación integral del monumento, reconocido como tal desde 1931. Del mismo modo, la puesta en valor ha sido preocupación de la población en general, ya que la catedral se ha convertido en un hito de identidad de la ciudad de Jaén, siempre muy vinculado, por razones obvias, a los conjuntos monumentales renacentistas de Úbeda y Baeza.

\section{Juan Manuel Becerra García}

Jefe de Servicio de Protección del Patrimonio Histórico Dirección General de Bienes Culturales

\section{Nota}

${ }^{1}$ Este articulo es un extracto del documento que para su declaración como Patrimonio Mundial ha sido presentado en la UNESCO en enero de 2011. 